\title{
Conceptos de espacio y tiempo en el arte andino
}

\section{Cristóbal Campana Delgado*}

“...el motivo del desinterés en cuestiones estéticas es ese miedo institucionalizado que tiene la ciencia ante lo inseguro y discutible, pero no el miedo del provincianismo ni del abandono de los planteamientos, muy por detrás de los temas a que tiendan..." T. Adorno, 1980.

\section{0.- Introducción y deslinde}

Todo lo que percibe la inteligencia humana es susceptible de ser convertido en símbolos de concordada significación. Así, en símbolos, se memoriza y acumula lo que entendemos por experiencia y "conocimiento". Lo que había sido una realidad natural en su entorno se torna en otra realidad; más aprehensible, manejable y plástica. Sólo así esa nueva "naturaleza" puede ser comunicada, es decir, puede tener un uso "común" para la sociedad. Por eso es necesario comprender que todo lo que procesamos se da en el campo conceptual y que cada concepto tiene referencia y significación dentro de una cultura. Allí radica nuestro primer problema: no conocemos bien los conceptos de "espacio" y "tiempo" en el pensamiento andino.

En la propia cultura occidental estos dos conceptos responden a complejas modificaciones históricas, tanto en el uso común como en los campos de la Filosofía, la Tecnología y la Ciencia. Los conceptos de "espacio" y "tiempo" son multívocos, pues cada voz o concepto tiene variadas acepciones. En este caso y en nuestro lenguaje, uno y otro concepto necesitan un deslinde previo ya que ambos expresan conceptos diversos en el mundo andino. En algunos casos una misma palabra puede expresar ambos, como sucede en el runa simi, donde la palabra "pacha" es a la vez "tierra" o espacio productivo o maternal y también es "tiempo", fenómeno eventual, modificador y reordenante. Incluso en el castellano estos conceptos tienen acepciones coincidentes en determinados "momentos" ya que podemos decir que "espacio" es el "transcurso de tiempo entre un punto y otro" y también "tardanza, lentitud"1 , similares a la definición de "tiempo", entendido como la distancia entre un punto y otro, o como "Lugar, proporción o espacio libre entre otras actividades"2.

Por lo tanto, si en la lengua andina, que conocemos mejor, se trata de dos conceptos diferentes que a la vez pueden ser expresados con una misma voz, es posible que el artista andino desde muy temprano los haya diferenciado y a la vez fusionado, tal

e-mail: ccampanad@hotmail.com

Diccionario de la Lengua Española, 19 Edic. Madrid, 1970. Esta palabra tiene 17 acepciones.

2 Diccionario de la Lengua Española, 19 Edic. Madrid, 1970. Esta palabra tiene 20 acepciones, más las formas del verbo. En el Diccionario Larousse editado en el 2002 aparecen varias acepciones nuevas para ambos conceptos así relacionados. 
como aparece expresado o registrado en las diversas obras artísticas anteriores a la llegada de los castellanos. Aquí surge nuestro problema: ¿Cómo representaron en un lenguaje no oral esos conceptos? ¿Cómo debemos leer y entender en las imágenes visuales, tales conceptos?

Intentaremos analizar cómo es que se estructura un nuevo espacio simbólico que, representando al espacio real y natural de su entorno, represente a la vez al tiempo de los sucesos allí acaecidos y acontecidos, así como la manera en que ese "espacio plástico", organiza objetos, seres y acontecimientos, que pueden ser comunicados. Ese es nuestro objetivo, entender las imágenes que aparecen en un espacio bidimensional, representando paralelamente la cuarta dimensión de dicho espacio, es decir, al "Tiempo". Es evidente que para los ejecutantes de entonces, conociendo los cánones y maneras de expresarse y representar las cosas, no debió resultarles tan difícil, pero para nosotros, que estamos fuera de su cultura puede parecernos algo enredado o sofisticado, por decir lo menos. Por eso será necesario que se explique la manera y el "cómo" nuestros antepasados disponían las formas en ese "espacio plástico" de modo que podamos entender el discurso detrás de lo que ahora nos resulta puramente visual.

\subsection{El Paisaje, la naturaleza, los hechos y su simbolización}

Por lo observado sabemos de antemano que, tal vez, antes que la propia imagen humana, lo primero que se intenta representar es el paisaje del entorno. Todo eso constituye una valiosa información que explica los procesos de comprensión del mundo. En las primeras representaciones, como las del arte rupestre, aparecen también conceptos relacionados con esos elementos y formas del ambiente; concepciones que aún no hemos podido entender o decodificar pues hay en esas primeras imágenes, otras, aparentemente simples, como puntos, rayas, cuadrículas, formas serpentinas, círculos, etc., de cuya comprensión estamos muy lejos. Solemos contentamos en varios casos con decir que se trata de "figuras geométricas simples", que "carecen de sintaxis", que "no permiten una lectura lineal", que "son formas rudimentarias", etc. Sólo en épocas avanzadas, cuando las imágenes nos permiten identificar caracteres, género, especies u otros rasgos, creemos que existe una relación más directa entre el espacio real y el espacio simbolizado.

El paisaje donde vive el hombre es cambiante al ser modificado de acuerdo a sus necesidades. Esos cambios no le impactarán tanto como cuando los violentos agentes de la naturaleza lo modifican, lo cual le hará pensar que no está sólo y que esas fuerzas le son ajenas. De allí deducirá los fundamentos de lo sagrado o divino: La invención de sus dioses. De esa fenomenología surgirán las expresiones que los representan, como espacio mismo, o como plantas, animales u otros caracteres que le impactaron. Lo que represente en ese "espacio plástico" mostrará en parte sus conceptos sobre el mundo que le rodea y las fuerzas que rompen o cambian su espacio como el "pachacuti", por ejemplo, o sobre si mismo. Todo lo que parecía "ordenado", cambia o se modifica y habrá que reordenarlo, tanto en la realidad como en lo simbólico, pues estamos convencidos que: “Toda comunidad humana organiza el espacio material en que vive $y$, por consiguiente, debe segmentarlo y jerarquizarlo, producir planos de continuidad y ruptura, órdenes en distintos niveles de significado" (Foucault 1984: 49). 
Si bien es cierto que Foucault se refiere al espacio arquitectónico, también es cierto que cualquier grupo humano modifica el espacio donde vive, primero, depredándolo, por la caza o por la recolecta de raíces, frutos o semillas, o después, cambiándolo con sus campos de cultivo. Pero icómo representó esas modificaciones o esos hechos acaecidos, cotidianamente o acontecidos eventualmente en ese espacio? Muy poco sabemos de eso. Pues lo que sí aparece es la representación de sus actos frente a su espacio, como podemos observar en los petroglifos de una piedra en el Alto de Las Guitarras, que muestra una escena de caza (fig.1).

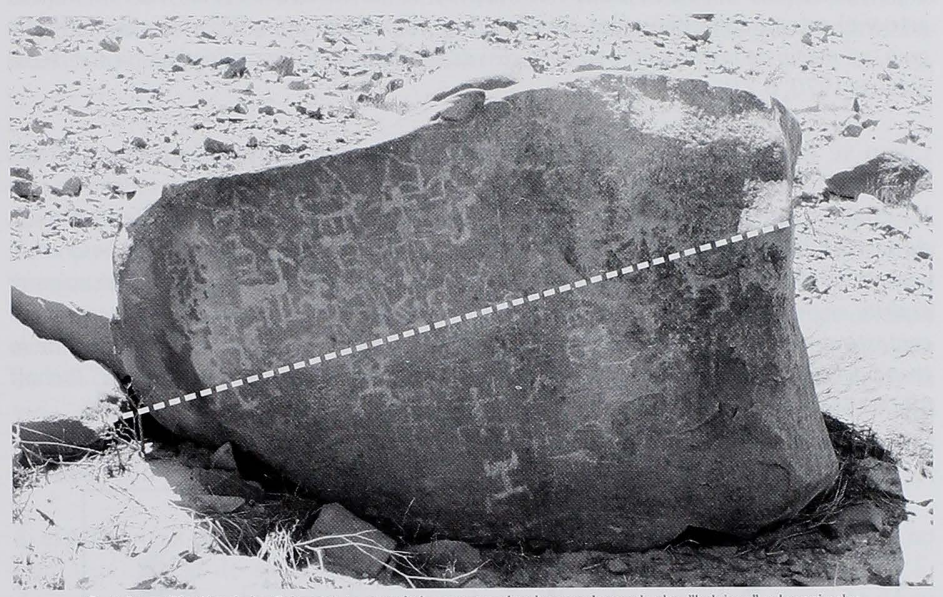

(fig.1) Petroglifo (Alto de las Guitarras): La parte baja corresponde a los cazadores y la alta -"lo lejano"- a los animales

No olvidemos que el escenario donde actúa el hombre es simbólico y que, todo aquello que entendemos como elaboración mental, como un constructo de su "pensamiento" o como su "cosmovisión”, son los conceptos, ideas y símbolos que le permitirán rodearse de un nuevo "espacio" que le es más accesible y manejable.

Debido a estos fenómenos derivados de su relación con el paisaje o espacio, podrá entender su importancia, las posibilidades de subsistencia que le ofrece, sus debilidades y deficiencias y, pretendiendo entenderlo mejor para así manejarlo, creará a sus deidades dotándolas con las fuerzas que él no posee. Esto es muy importante, pues, "Damos nombre de dios a la forma que mejor traduce nuestro deseo. Esa forma puede ser sensual, moral, individual, social iqué más da! Se trata de nuestro indefinido deseo de comprender, de utilizar la vida, de hacer retroceder sin cesar los límites de la inteligencia y del corazón" (Faure 1966: 16).

Esto que pareciera un tanto alejado de nuestros objetivos no es tal pues la creación de las deidades por cada sociedad, planteará la concepción y la existencia de un "espacio sagrado" en donde "nacen" o de donde "vienen" las deidades, espacio que generalmente existió y en donde esa sociedad inicia su desarrollo, o en donde están los recursos de mayor interés. Así mismo, asociado a ese "espacio sagrado" hay un "tiempo sagrado" que les recuerda los hechos, eventualidades y acontecimientos 
entre hombres y deidades, los más importantes de su pasado. Ese será el "tiempo" que siempre debe ser recordado en ceremonias y ritos. Es el tiempo que "retorna" y se "recrea" generando calendarios y agendas ceremoniales. Esas serán las ceremonias donde coinciden "espacio" y "tiempo" para reordenar la vida.

La representación del "espacio" y del "tiempo" en las imágenes andinas debió estar a cargo de verdaderos artistas, quienes actuaban dentro de las pautas del estilo y época de sus respectivas sociedades, pues a otra persona que no tuviese esa capacidad y experiencia para expresar ideas y conceptos, le sería imposible. De esta manera el arte y el artista cumplían roles sociales muy valorados, pues "El arte es también una guía, un medio de instrucción y yo diría casi de aprendizaje de la realidad ambiente". (Levi Strauss 1970, p.21).

Como se deduce, en las manos del hombre que representa plásticamente esos espacios, los momentos más importantes de su vida y la de sus dioses, entran en uso los códigos que posibilitan esa representación simbólica y a la vez la diferenciación de la realidad que transcurre y que le rodea. Allí, “....esta distinción se basa en la concepción filosófica, implícita o explícita, que existe fuera e independientemente de cualquier espíritu cognoscente; por otra, el pensamiento relativo a dicha realidad. Solamente en el contexto de esa concepción y de esta distinción se plantean los múltiples problemas de la teoría del conocimiento que [... J también son válidos para la teoría de la historia..." (Schaff 1974:156).

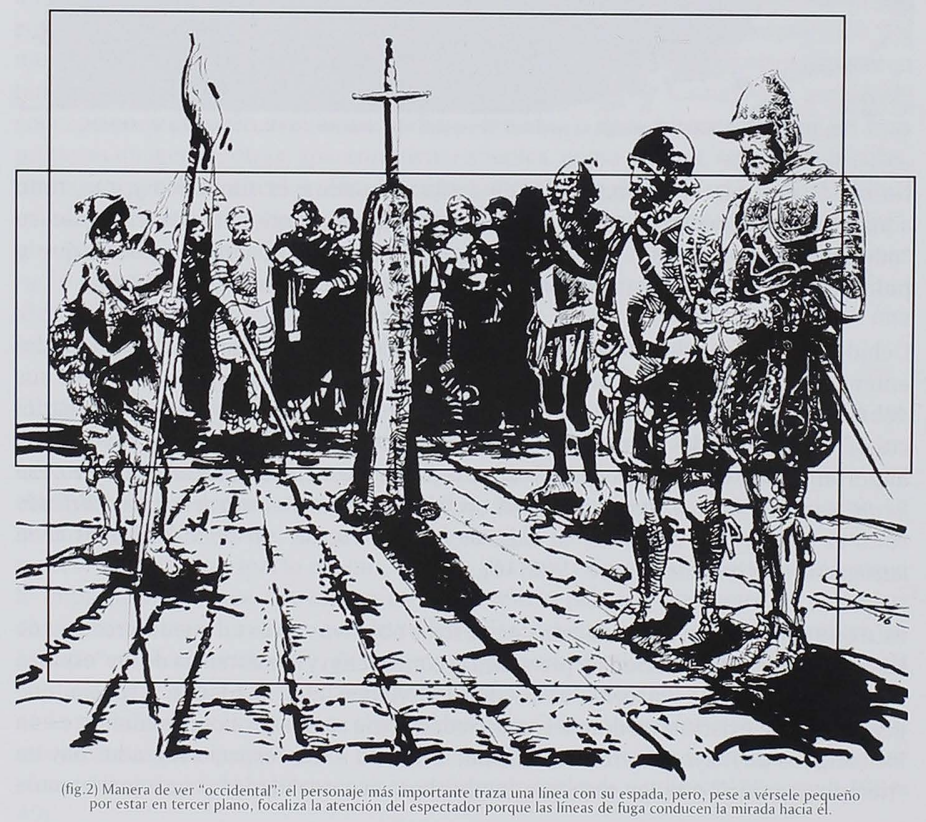


La realidad es sólo una manera de entendimiento y aprehensión. No existe "una realidad", sino una visión de ésta. Visión determinada por la cultura, la que con sus "principios" y "conceptos" va pautando nuestra forma de ver el mundo. Con esas pautas obtenemos el conocimiento del entorno y de lo que el hombre hace. Esto es tan claro que visto así, el espacio, como parte de la realidad, es un concepto cultural, pues "La ciencia ha demostrado que la realidad no es la que percibimos, sino la que cada persona se crea, a partir de su propio concepto de realidad desde su percepción personal." (Villafaña Gómez 2003: 17). Es decir, la realidad es la visión que nuestra experiencia adquiere con referencia a lo que nos rodea, al igual que la forma de "leerla", la misma que compromete a los miembros componentes de una sociedad. Ese compromiso obedece a que a que es aprendida y pautada (fig. 2).

\subsection{El "espacio plástico" y el "yanantin": la dualidad de la existencia}

En el pensamiento andino todo lo existente es dual. No como un sistema ideológico de oposiciones excluyentes, sino como un sistema de complementariedades integradoras y concurrentes. Estas interpolaciones deben derivarse de la necesidad constante de reciprocidad para supervivir en paisajes tan agrestes o difíciles como el andino. La idea del "yanantin" abarca y define todos los conceptos de la vida humana en relación con la naturaleza (pachamama). Aparece desde el mismo instante de la vida, donde es "pacareq" y se recrea en las relaciones productivas y sus racionales reciprocidades del ayni y la minqa. Como veremos más adelante, esto influye en los medios y códigos de representación de las cosas en el "espacio plástico".

Si el hombre es una parte de la tierra o de su espacio, es decir de la pachamama, no podrá desligarse de su ubicación temporal y estará en un mismo plano que lo distante, por ser parte integral de ese todo. Es decir, éste no estará separado de su ámbito de origen, de su pacareq. Entonces, existirá siempre (no eternamente) en el punto donde se une con la tierra. Allí desarrolla y desarrollará sus actividades y todos sus actos en gestión de su historia. Posiblemente, dentro de estos conceptos, el hombre aparecerá en el plano que se inserta en la tierra, es decir, bajo sus propios pies, sin estar separado de lo distante que representará de otra forma (fig.4).

Cuando nos referimos a éste concepto de espacio, forzosamente tenemos que deslindar, primero, dónde y cómo se ubica el observador que generalmente equivale al artista o ejecutante. El estudio de toda representación del espacio implica ubicar el lugar desde el cual el artista "vio" el escenario y cómo concibió las distancias o planos dentro de él, y qué relación tiene su ubicación en el espacio circundante representado, para que de esa manera podamos "leer" lo cercano y lo distante, es decir, la noción del tiempo en el "espacio plástico". La visión occidental está pautada por las leyes de la perspectiva (fig.2), mientras que la visión andina está pautada por la concepción de dualidades y reciprocidades, indesligables, entre la tierra, el hombre y el tiempo (fig. 4). 


\subsection{El ordenamiento del espacio y su simbolización}

Todo el sistema de dualidades para el hombre andino se orienta a entender que sólo así es posible mantener el equilibrio de la vida; de allí que nada en el espacio es menos importante que lo otro. Las nociones espaciales de "arriba-abajo" (hanan-hurin), "izquierda-derecha" (ichoq-rancha) son factores concurrentes que no se excluyen entre sí porque ninguna es mejor que otra y así se asocian a la sexualidad como origen de la vida, de tal manera que el lado izquierdo es femenino y el derecho, masculino, tal como se advierte en la leyenda fundacional del Cuzco cuando Manco Cápac cruza el río Huatanay para ubicarse arriba, en el "hanan", y Mama Ocllo se queda en la parte baja o "hurin", para fundar simbólica y factualmente las respectivas dinastías. Esto no establecía diferencias asimétricas entre "uno mejor que otro"; era el equilibrio necesario en un mundo de inseguridades y fenómenos meteorológicos y telúricos de extrema gravedad.

\section{2.- El tiempo, las actividades y la vida}

Las actividades que tuvieron sociedades tan religiosamente estructuradas como las andinas, planteaban la asunción y, a la vez, la diferenciación de las mismas. Esta diferenciación generaba, básicamente, dos tipos de tiempo: un "tiempo cotidiano" y un "tiempo ceremonial". Ambos son concurrentes. En el primero, todo "acaece" y, en el otro, todo "acontece". El primero sucede en el campo, en la "pachamama", accionando para "shay" y "kashay", ser y existir. El segundo recuerda cíclicamente los grandes acontecimientos, y su existencia se da en la "huaca" o templo-deidad.

Si quisiéramos definir la vida de alguna manera diríamos que es la suma de nuestras actividades a través del tiempo. Así, en su expresión en el "espacio plástico", encontraríamos que se tenían dos modos de entender el tiempo: como lo que trascurre o "tiempo transcurrente" o como la suma del tiempo que envejece o "tiempo trascurrido". O como dijimos antes, al estudiar la escena de un taller de maestras tejedoras, de edad y señores que trocaban: "el tiempo que transcurre es la distancia entre una y otra persona, y el "tiempo transcurrido" se observa en el rostro de cada una de estas. Si se tratase de una escena mítica, por ejemplo, las arrugas se inscriben más en el discurso mítico que en la edad de las personas. Si al tiempo se le define en este caso 'como la duración de las cosas sujetas a mudanza', necesitamos descubrir estas relaciones, pues ello nos permitirá entender qué personas se relacionan con quién en un sector del taller, y ese sería el "tiempo transcurrente" (Campana 1994: 450).

En un templo o en una Huaca el tiempo transcurre cíclicamente asociado a sus ceremoniales, calculados experimentalmente. En la huaca se gesta y gestiona lo referente a la subsistencia por medio de ceremonias y ritos, con calendarios concordados para ser obedecidos. Cada forma del tiempo tendría a su vez una manifestación artística. El tiempo religioso y ceremonial exigía un ritual esotérico y un arte especializado. En cambio, el tiempo cotidiano, artesanal o agrícola, debió ser una manifestación más de la naturaleza de las cosas, de la necesidad, de la

En los dos casos se trata de sucesos asociados a diversos grados de importancia. De lo que "acaece" poco se guarda memoria, y lo que "acontece", se convierte en memoria colectiva, en ceremonial ritual y mítico. 
herramienta y el utensilio, del accionar común y profano. Pero ambos fundamentaban con sus actos la necesidad de la vida.

Todo esto, en realidad, parecería distante del objetivo central de este estudio, pero no es así, pues son concurrentes y así aparecen en las representaciones, ya que ambos se expresan simbólicamente y, "En este caso, una parte del complejo de objetos denotados por el significante se convierte -por metonimia- en el propio significante. Una parte del referente se semiotiza y se hace arbitrariamente simbólica de todo el complejo al que se refiere" (Eco 1973: 91). Esta opinión nos parece muy interesante pues explica y justifica cómo los artistas andinos llegan a convertir simbólicamente el espacio en tiempo: el suelo que es horizontal, en plano vertical, es decir, expresan los efectos usando las causas que lo originan (fig. 4).

Las tareas y actividades secuencialmente expresadas para representar el tiempo, requieren de su conversión a símbolos para su representación, tal como las vemos, por ejemplo, en varios huacos de la alfarería mochica. Estamos seguros que en cada elemento significante así como en sus formas de agrupación "el signo icónico construye un modelo de relaciones (entre los fenómenos gráficos), homólogo al modelo de relaciones
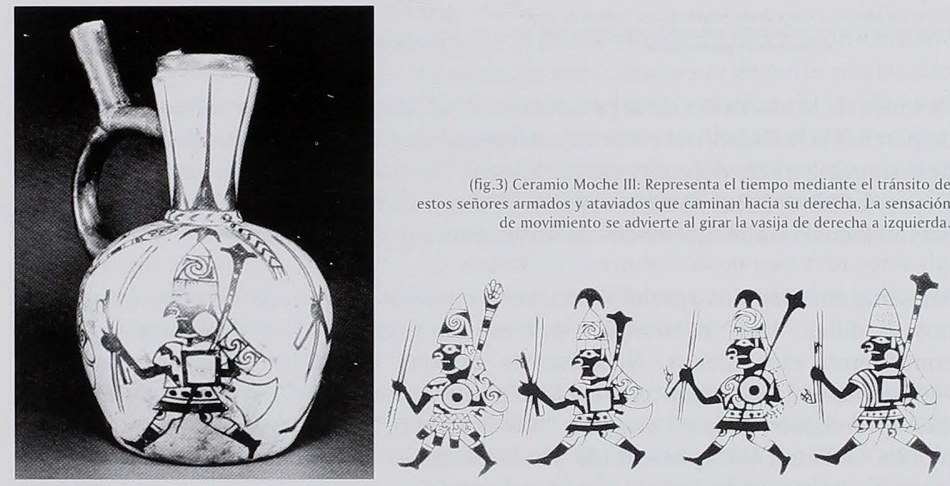

perceptivas que construimos al conocer y recordar el objeto [...], ante los signos icónicos podemos afirmar que se pueden entender como a tal lo que parece reproducir algunas de las propiedades del objeto representado" (Eco 1973: 234).

Para la representación del "tiempo transcurrente" los artistas mochicas, recurrían a representar las imágenes en el "espacio plástico", dándole un sentido a sus movimientos o desplazamiento. En otros casos, fue realizada de otras maneras: en secuencias horizontales (fig.3), o en espirales ascendentes. En cualquiera de estas dos formas implicaba girar el huaco en el mismo sentido en que apareciesen sus pies. Es interesante observar que esta representación del tiempo "en movimiento" no aparece tempranamente con un interés de simbolizarlo, pues las imágenes eran mayormente frontales y "congeladas", tal vez para representar su carácter sagrado. 


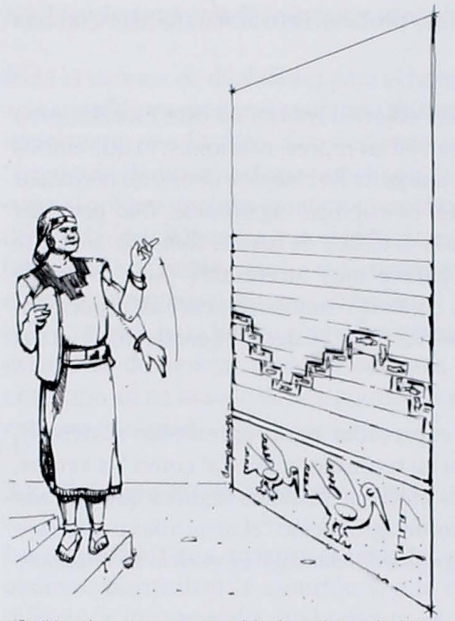

(fig.4) Los planos se superponen exigiendo una lectura de abajo hacia arriba y no en profundidad como en la perspectiva. Asi, el sujeto está en primer plano.

\subsection{El Espacio, los planos y las distancias}

Ya hemos visto cómo la cultura condiciona nuestra forma de ver, lo que se refleja en su forma de representación y que, en el caso del espacio y del tiempo, lo que quiere decir, es que hay muchas maneras de ver, entender y representar el espacio. Para los que heredamos el conocimiento occidental, hemos aprendido a "ver" dimensiones y distancias de acuerdo a la perspectiva y hemos convertido y adaptado a sus reglas nuestro discurso oral, pues tenemos "un punto de vista" diferente al de los otros o, cambia la altura del "horizonte" según nuestra personal estatura, o nuestros grados de interés por las cosas a las que ubicamos en los "planos" que le correspondan (fig.2).

Después de la invención de la perspectiva en el Renacimiento se define otra manera de percibir la realidad, del entorno y su representación. Todos entendemos la noción de distancia a través del concepto de "planos", unos detrás de otros y así, conforme se alejan, disminuyen las dimensiones. Y, a la inversa, el tiempo es mayor, cuando vemos más alejados o empequeñecidos dichos planos (fig.2).

Nuestros antepasados aprendieron a ver y comunicar esa noción de una forma, que nos es difícil "leer" o entender, por eso necesitamos "ver" cómo es que ellos concibieron esos planos. Necesitamos explicar la ubicación de su noción de "horizonte" y dónde situaron el suelo o "punto de ubicación" del observador. Una vez que aprendamos a "leer" esa otra "retórica visual", podremos ver y entender con mucha facilidad lo representado en los espacios con imágenes hechas por los antiguos artistas andinos.

Si el ambiente es lo primero que el hombre asume y procesa, convirtiéndolo en un conjunto de símbolos para poder manejarlo de acuerdo a sus necesidades, entonces plantea "acuerdos" entre los demás miembros de la sociedad, de lo contrario no podrá entenderlos. Lo que implica la existencia de una "retórica" visual completamente comprensible por los suyos. Un estilo siempre implica concordancia y consentimiento entre ejecutantes y observadores, pues dentro de esa "retórica", tanto simbólica como visual, expresará la representación del orden social que le rodea.

En el Palacio Tschudi en Chan Chan hay varios ejemplos y el más grande es el del patio central donde podemos ver un paisaje marino en tres planos superpuestos: abajo la playa por donde caminan los "anzumitos" o gatos marinos (Lutra felina), en el segundo nivel está el mar y sus olas, y arriba una plano "vacio" que representaría el cielo (fig. 5). 
Otro ejemplo que nos parece más didáctico para entender la forma de concebir el "espacio plástico", es el que hicieron los artistas chimúes, en el friso conocido como "Corredor de aves y peces" que está en el costado derecho del patio principal de Tschudi. En este corredor vemos que a todo lo largo del tramo que va de norte a sur, como si se dirigiese al mar, hay un conjunto de tracerías en relieve que muestran aves caminando, peces dentro de formas escalonadas, una serie de líneas horizontales rectas y, finalmente, un gran espacio plano en la parte más alta (fig.4). Se trata de un paisaje marino en dinámico movimiento, cuyas imágenes están representadas en tres planos dispuestos unos sobre otros; a diferencia de nuestra manera occidental de ver, que pone los planos unos detrás de otros, como nos enseñó a observar la perspectiva.

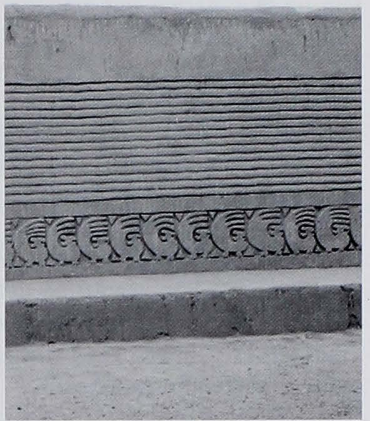

(fig.5) En primer plano -abajo- corren los anzumitos: en tercer plano -arriba- el cielo despejado.

El primer plano corresponde al suelo donde el artista se ubicó y ubica al observador. En él hay una primera franja lisa donde están las aves caminando de perfil con las alas a medio desplegar. Luego hay otra franja donde termina la noción de "orilla" y el primer plano. En el primer sector del pasadizo las aves se dirigen al sur, como si debiéramos entender que van hacia la orilla. En el segundo sector más largo, las aves parecen venir o regresar de la orilla. Las aves tienen las alas y la cola en una posición convencional para hacer notar su presencia, muy en especial la cola, pues está rebatida para que se vea en plano y no de perfil. Esto quiere decir que ésta parte del ave no se ve "de perfil" como las otras. Parece ser que hay una actitud mágica que intenta mostrar una imagen de frente y de perfil, al mismo tiempo.

El segundo plano corresponde al mar, con sus olas y sus ondas. Éste comienza después de una cinta plana que nos recuerda la orilla mojada y brillante. El mar se descompone en "olas" y "ondas". Las primeras están representadas por una franja de formas escalonadas que suben y bajan, dentro de ella vienen los peces. Las "ondas" están representadas por líneas rectas horizontales muy bien pulidas, la parte superior es más honda que la inferior como si fuese la cinta de una persiana, lo que acentúa la idea de que "vienen" desde atrás o sea desde lejos. En el tercer y último plano hay un gran espacio vacío que representaría a un cielo limpio o sin nubes.

En la franja escalonada cada uno de sus tramos es cortado por cuatro de estas líneas horizontales, las cuales en su largo conjunto representan las olas en su ritmo constante. Esta franja tiene a su vez tres cintas paralelas: dos en sus extremos, inferior y superior, y en el centro está la zona por donde vienen los peces. La primera cinta escalonada al subir y bajar en sus cuatro tramos, conforma una pirámide. Como hay otra cinta más alta y paralela permite la recurrencia interior de los peces, dos en cada tramo, uno horizontal y el otro vertical. La sucesión de esta forma escalonada es una larga secuencia de olas y parece sugerir que vienen desde el sur como expresando que los peces vienen con las olas del mar. 
En un tercer plano, sobre estas franjas, en la parte alta del muro, hay un espacio plano, vacío, sin ningún elemento decorativo. Éste debe ser el cielo limpio o, tal vez, brumoso, "más arriba y más allá del mar". Con estos tres planos se pudo representar un paisaje marino que impone un recorrido visual de abajo hacia arriba para ser entendido con facilidad. De esta manera, la línea divisoria entre el mar y el cielo, sería la "línea de horizonte", la misma que cambia de altura según varíe la estatura del observador (fig.4).

Las cifras asociadas del "segundo plano" o del mar, son muy interesantes: 21 peces en cada pirámide, 21 ondas marinas en la parte interior, igual número en la parte superior y 7 aves caminando en cada tramo de la ola. El análisis de las imágenes de aves y peces hace evidente que han sido logradas con los rasgos más sencillos y escuetos. Lo importante no debió ser la necesidad de representar esos animales naturalistamente sino como elementos de una visión integral del mar y sus formas más representativas. Las cantidades deben expresar algún evento marino, todavía no entendido por los estudiosos.

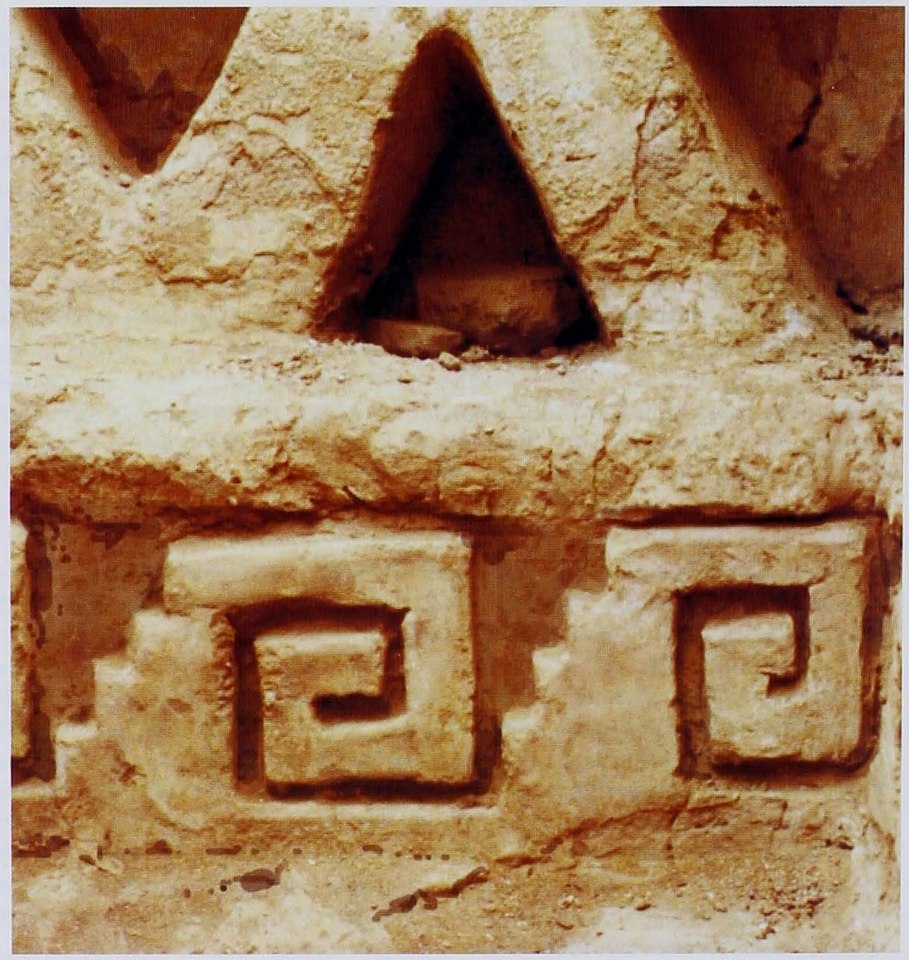

(fig.6) "Triangulo escalonado con ola": se pueden ver los espacios "positivos" -relieves-y "negativos" -sombras- 

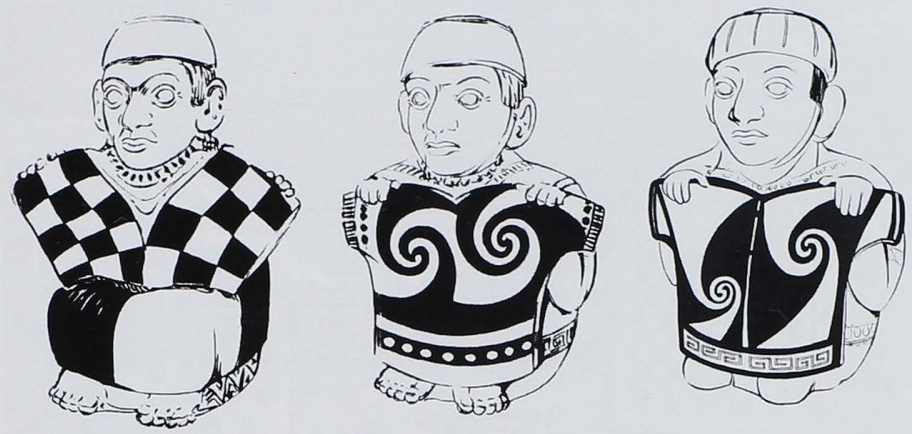

(fig 7) Dos de los trajes que ofrecen estos comerciantes Moche destacan el diseño tipo "ola", expresado como espacios "positivos" y "negativos"

\subsection{Espacios positivos y negativos}

Ya antes hicimos notar que en la polaridad de los espacios no existió ninguna valoración que impusiese uno sobre otro, sino que "uno" se explicaba o existía por "el otro". Un macho no se explica sin la hembra o viceversa, así como lo alto no existe sin lo bajo, lo bueno sin lo malo, etc. Bajo este presupuesto ideológico vemos que hay "espacios plásticos" representando imágenes simbólicas que siendo iguales son opuestas visualmente pues una aparece en blanco y su equivalente invertido diagonalmente aparece en negro. Este tema que aparece desde los tiempos finales del Período Inicial (1,800 a.C.), se acentúa con una maestría sin igual en tiempos Moche (100 a.C. - 700 d.C.) y prosigue en los tiempos Chimú sobre todo en su arquitectura (figs. 6 y 7 ).

Cuando estudiamos el arte Chavín, planteamos: “a.) Si entendemos como espacios "positivos" a los que pertenecen a la representación y "negativos" a los que la contrastan [...] Ilenaron espacios "dualmente" contrastando -por igual-sus figuras icónicas, pertenecientes a la teogonía religiosa. // b.) Tanto el espacio positivo como el negativo fueron desmenuzados en pequeñas áreas, no dejando campos netos, lo cual obligó a elaborar los espacios positivos para diferenciarlos de los negativos. Desmenuzado asi el espacio, cabe imaginar que el trabajo de la luz sobre la superficie fue puramente bitonal: luz y sombra. Luz para la superficie sobresaliente, ocupada por la representación y sombra para la excavada, conformando ésta, el espacio vacío o negativo. Es posible también que en algunas obras de alfarería, las incisiones hayan tenido algún pigmento que aumente la sensación de profundidad (Campana, 1995). A lo que ahora podríamos agregar que un "espacio positivo" equivale a lo masculino y su correspondiente "espacio negativo" a lo femenino.

\subsection{Un "espacio" submarino}

¿Cómo entendieron o "vieron" los artistas andinos los espacios interiores del mar o lo que hoy entendemos como submarinos? Hemos visto varias imágenes Nazca y Lambayeque, pero las que mejor lo describen pertenecen a los Chimú y pueden verse en los frisos de Chan Chan, específicamente en los palacios Velarde y Uhle. Se trataría 


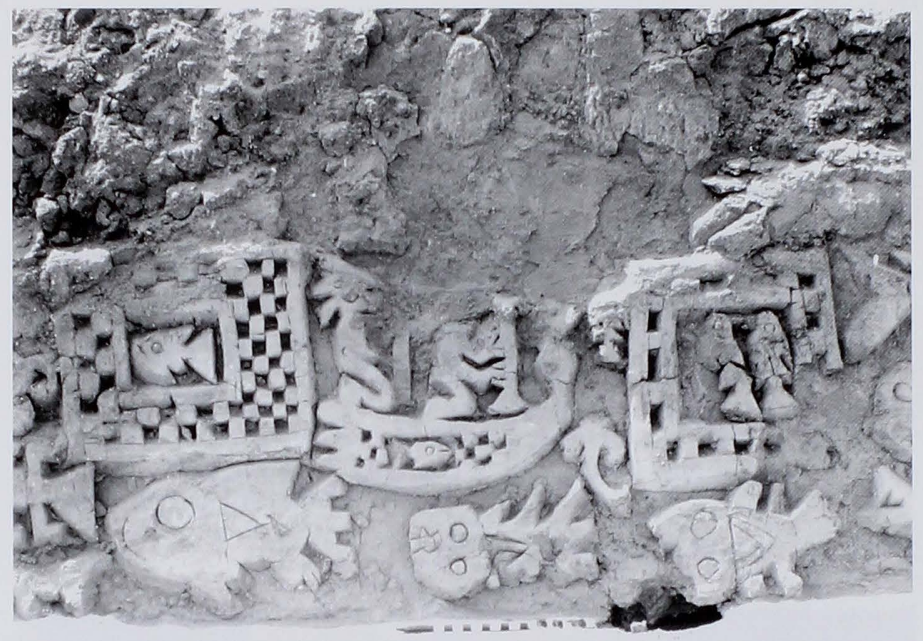

(fig.8) Pescadores sobre "caballitos" de totora. Aunque los sujetos aparecen de perfil presentan frontalmente su rostro y mediante una vista "a vuelo de pájaro" permiten ver los peces dentro de la embarcacion y las trampas que la rodean.

de imágenes quie narran acciones dentro del "espacio" submarino y su asociación con algún mito de origen o con explicaciones emblemáticas. Usaremos las escenas de pescadores en sus embarcaciones de totora que aparecen en un friso de Velarde y otra de nadadores que bucean en búsqueda del mullo (Spondylus) que aparecen representados en el zócalo de las hornacinas del palacio Uhle, respectivamente.

En uno y otro caso los pescadores usaban balsas o "caballitos de totora" para dos o más personas, lo que indicaría su mayor magnitud. Las embarcaciones aparecen en el plano superior, arriba; como si el que describe la escena estuviera bajo el nivel del mar. Otra característica común a las diversas escenas es que la embarcación estando de perfil, incorpora la visión perpendicular, desde lo alto, para que se vea su contenido.

Varias partes del cuerpo humano, tal vez las de menor importancia simbólica han sido simplificadas o casi abstraídas, como son el número de los dedos en pies y manos, las cejas del rostro, el pecho, etc. Esta manera de representar pasaría desapercibida, si es que con otras cosas o artefactos no ocurriera lo mismo.

Es interesante observar cómo, por ejemplo, las embarcaciones o "caballitos de totora" estando de perfil muestran también "de frente" su contenido (fig. 8). Todas las trampas o criaderos de peces y moluscos que hay en el espacio submarino, son mostrados como mejor les habría parecido para describir las correspondientes especies marinas, unos de perfil y otros "de frente", pero desde arriba. Entonces esto demostraría que sí hay un "concepto" convencional en mostrar ciertas partes o aspectos de perfil y otros de frente y viceversa. Frente a todos estos planteamientos para la visualización de las representaciones del espacio, las preguntas que nos 
quedarían por responder son: ¿Por qué al cuerpo humano no se le representa de frente y perfil a la vez? ¿Por qué la cola de las aves aparece como vista de frente estando el cuerpo de perfil? ¿Por qué sólo el ojo humano es presentado de frente, estando de perfil o de frente la imagen humana? Como podemos observar, estamos entrando en el terreno de los conceptos y con ello a la tendencia abstractiva y puramente convencional de las imágenes.

De lo expuesto, y para finalizar, se deduce que los artistas andinos actuaron desde milenios atrás bajo los lineamientos de una ideología religiosa que concebía las nociones de espacio y de tiempo como unidades duales, comprometiendo otras esferas como lo sexual, que da origen a la vida y a ésta como existencia dinamizada por factores concurrentes y sin valoraciones excluyentes.

\section{BIBLIOGRAFÍA}

Campana, Cristóbal. Arte Chavín. Análisis estructural de formas e imágenes. Universidad Nacional Federico Villarreal, Lima, 1995.

Campana, Cristóbal. "El entorno cultural en un dibujo mochica" en: Moche, propuestas y perspectivas. Santiago Uceda-Elías Mujica Editores, Trujillo, 1994.

Eco, Umberto. La definición del arte. Ediciones Martínez Roca, S.A., Barcelona, 1970.

Eco, Umberto. La estructura ausente. Editorial Lumen. Barcelona, 1973.

Faure, Élie. Historia del Arte. Tomo I.. Editorial Hermes S.A., México, 1966.

Foucault, Michel, "Des espaces autres” en MC Revue D'Architecture. Oct: (46-49), 1984.

Levi-Strauss, Claude. Antropología Estructural. EUDEBA, Buenos Aires, 1968.

Levi-Strauss, Claude y George Charbonier. Arte, lenguaje y etnología (Entrevistas con George Charbonier). Instituto del Libro, La Habana, 1970.

Schaff, Adam. Historia y verdad, ensayo sobre la objetividad del conocimiento histórico. Eitorial Grijalbo, Colombia. Teoría y Praxis, México, 1974.

Villafaña Gómez, Georgina. Educación visual. Editorial Trillas, México, 2003. 
